\title{
FORUM
}

\section{CORPORATE SOCIAL RESPONSIBILITY PRACTICES AT BRAZILIAN FIRMS}

\author{
Práticas de responsabilidade social corporativa em empresas brasileiras \\ Prácticas de responsabilidad social corporativa en empresas brasileñas
}

\begin{abstract}
Corporate Social Responsibility practices have been on the rise in recent years in firms all over the world. Brazil, as one of the most important countries emerging on the international scene, is no exception to this, with more and more firms taking up these practices. The present study focuses on analyzing the corporate social responsibility practices that Brazilian companies engage into. The sample used is comprised of 500 firms grouped by geographical area; the theoretical framework is based on stakeholder and institutional theories; and the technique used for the analysis is the biplot, more specifically the HJ Biplot and cluster analysis. From the results obtained it is possible to infer that the CSR variables corresponding to environmental practices are more closely linked to companies located in the northern areas of Brazil. Social and community practices are related to companies primarily in the southern and northeastern regions of the country.
\end{abstract}

KEYWORDS / Corporate social responsibility practices, stakeholder and institutional theories, Brazilian companies, HJ biplot, cluster.

\section{RESUMO}

As práticas de Responsabilidade Social Corporativa têm aumentado nos últimos anos em empresas de todo o mundo. O Brasil, um dos mais importantes países emergentes no cenário internacional, não é uma exceção a isso, com mais e mais empresas que optam por tais práticas. O presente estudo concentra-se na análise das práticas de responsabilidade social corporativa com as quais as empresas brasileiras estão envolvidas. A amostra utilizada é composta por 500 empresas agrupadas por área geográfica; o quadro teórico baseia-se nas teorias institucionais e de partes interessadas; e a técnica utilizada para a análise é o biplot, mais especificamente o HJ biplot e a análise de agrupamento. Com base nos resultados obtidos, é possível inferir que as variáveis de RSC correspondentes a práticas ambientais estão mais intimamente ligadas a empresas localizadas nas áreas do Norte do Brasil. As práticas sociais e comunitárias estão ligadas a empresas localizadas principalmente nas regiões Sul e Nordeste do país.

ISABEL GALEGO-ÁLVAREZ

igallego@usal.es

Professor at Faculty of Economics,

University of Salamanca, Salamanca - Spain

\section{HENRIQUE FORMIGONI}

henrique.formigoni@mackenzie.br Coordinator at Graduate Program in Accounting, Universidade Presbiteriana Mackenzie, Sao Paulo, SP - Brazil

\section{MARIA THEREZA POMPA ANTUNES}

mariathereza@mackenzie.br Coordinator at Graduate Program

in Accounting, Universidade

Presbiteriana Mackenzie, Sao Paulo, $S P$ - Brazil
PALAVRAS-CHAVE | Práticas de responsabilidade social corporativa, teorias institucionais e de partes interessadas, empresas brasileiras, HJ biplot, agrupamento.

\section{RESUMEN}

Las prácticas de Responsabilidad Social Corporativa han aumentado en los últimos años en las empresas de todo el mundo. En Brasil, uno de los más importantes países emergentes en el escenario internacional, no es la excepción, con muchas más empresas que optan por tales prácticas. El presente estudio se concentra en el análisis de las prácticas de responsabilidad social corporativa y cómo las empresas brasileñas están comprometidas. La muestra utilizada está compuesta por 500 empresas agrupadas por área geográfica; el cuadro teórico se basa en las teorías institucionales y de partes interesadas; y la técnica utilizada para el análisis es el biplot, más específicamente el HJ biplot y el análisis del agrupamiento. Con base en los resultados obtenidos, es posible inferir que las variables de RSC correspondientes a prácticas ambientales están más intimamente relacionadas a empresas localizadas en las áreas del Norte de Brasil. Las prácticas sociales y comunitarias están relacionadas a empresas localizadas principalmente en las regiones Sur y Nordeste del país.

PALABRAS-CLAVE I Prácticas de responsabilidad social corporativa, teorías institucionales y de partes interesadas, empresas brasileñas, HJ biplot, agrupamiento. 


\section{INTRODUCTION}

In recent years, particularly starting in the 1980 s, interest in the practice of corporate social responsibility has increased worldwide. On one hand, companies are becoming more and more interested in legitimizing themselves before society and raising awareness of their responsible practices, and on the other hand, society is more interested in knowing that companies are indeed practicing social responsibility.

In the present study we focus on an emerging country, Brazil, which has become a point of reference for the business community; many Brazilian companies have adopted social policies while following the guidelines proposed by the Instituto Ethos (Casanova \& Dumas, 2010), and according to Correa, Flynn, \& Amit (2004), Brazil is the Latin American country where corporate social responsibility has been given the most importance and where close to 500 companies have reported following the guidelines proposed by this Institute.

More and more frequently entrepreneurs and executives undertake business projects giving a clear priority to corporate social responsibility practices (Griesse, 2007, Scharf, 2009, Young, 2004, Barin-Cruz \& Boehe, 2010). For example, in 1995 Rodrigo Baggio created the NGO Comitê para Democratização da Informática (CDI) with the goal of using information technology as a tool to socially include low-income communities. This model has been extended to other emerging countries such as India. Companies like Natura, for example, not only publish corporate social responsibility practices in sustainability reports following the Global Reporting Initiative (GRI, 2011) guidelines, but they have also integrated corporate social responsibility practices as part of their business strategy. Another example of companies taking on corporate social responsibility practices is Petrobras, which has adopted these practices as an integrated part of its core business strategy and actively participates in many diversified social activities.

These references clearly show the important role that Brazil plays as a pioneer country in Latin America when it comes to corporate social responsibility. The present study focuses on analyzing the corporate social responsibility practices that Brazilian companies engage in. To do so, we used the HJ Biplot and cluster technique to interpret the data provided by the Instituto Ethos on 500 Brazilian companies belonging to different sectors of activities and practicing CSR.

The specific aim of this research was to find out whether the CSR practices of 500 firms in one country are the same or different according to the geographical areas within that country, and whether companies within those areas employ similar
CSR practices or not. As our theoretical basis we turned to both the stakeholder and the institutional theory.

According to Deegan and Unerman (2011, p. 369) both of these theories fall under the socio-political economic perspective: while stakeholder theory explains why managers might embrace specific strategies, institutional theory tends to explain why managers will be subject to pressure to change or adopt certain voluntary corporate social responsibility practices. These pressures can be coercive, mimetic and normative.

From the results obtained it was possible to infer that the variables corresponding to responsible environmental practices are more closely linked to the companies located in the northern areas of Brazil, whereas other variables representing social and community practices are related to companies from the south and northeast of the country. It can be highlighted that companies in the southeast of the country tend to focus on product responsibility.

These findings show that, viewed from the stakeholder theory, CSR practices differ from one geographical area to another and that, furthermore, within each geographical area, there are social pressures that create uncertainty. Companies therefore tend to mimic the activities of local rivals in order to reduce uncertainty and gain legitimacy, thus leading us into the territory of institutional theory.

The paper is structured as follows: following the introduction, in section 2 the theoretical framework of corporate social responsibility is established, and different theories regarding the topic are discussed. In section 3 the research method is addressed, with a description of the sample and the analysis technique. The results obtained are discussed in section 4 and in section 5 the most important results are summarized, as are the limitations of this research; the conclusions drawn are also presented in this section.

\section{CORPORATE SOCIAL RESPONSABILITY: THEORETICAL FRAMEWORK}

\section{Theoretical framework of social corporate responsibility}

Many theories developed by different authors have tried to resolve the open debate on an international level about the corporate social responsibility of a company. Within the theoretical frame of our research we focus on the so-called systems-oriented theories, which allow us to analyze the relations between organizations and interest groups, and more specifically, the socio-political economic perspective defined by Gray, Owen, 
\& Adams (1996, p. 47) as "the social, political and economic framework within which human life takes place".

The stakeholder and institutional theories come under these broader umbrella theories. The reason we turned to stakeholder theory is that one of our objectives was to find out whether the CSR practices of 500 firms in one country are the same in all of that country's geographical areas or not. Institutional theory likewise comes into play because we also try to determine whether companies within a certain geographical area have the same CSR practices or whether they differ owing to some kind of social pressure.

Thus, one of the most important precursors of stakeholder theory, Freeman (1984), maintains that managers should adopt their policies with a view to satisfying numerous stakeholders, the latter being defined as "a person or group that can affect or is affected by the achievement of the organization's objectives". According to this paradigm, stakeholders include customers, suppliers, employees, communities, and the general public, besides managers, stockholders and creditors, that is, not only a firm's own shareholders but also interested groups. This same author considers this theory to be about the meaning of good management and how persons can create value for each other.

He also argues that it is necessary to find ideas and concepts that help to integrate ethics and business, and that it is precisely businesses and executives who are responsible for those groups and individuals that can affect or be affected by a business organization (Agle, Donaldson, Freeman, Jensen, Mitchell, \& Wood, 2008, p. 164). In Freeman's (1984) stakeholder model, management becomes the guarantor of the interests of all parties involved, even at the risk of losing benefits for shareholders (Vasconcelos, Alves, \& Pesqueux, 2012, p. 149).

The theory underlying this idea of satisfying third parties and not only company shareholders is also defended by authors such as Donaldson \& Preston (1995) and Jones (1995). For these authors, companies should be honest and ethical in their interactions with interest groups since this type of behavior is beneficial for the company, an opinion also shared by Vasconcelos, Alves, \& Pesqueux (2012, p. 149).

Stakeholder theory accepts the existence of different interest groups with different ideas about what should be considered the optimum performance of a company, and different capabilities to affect an organization's activity (Deegan, 2002, p. 294).

Stakeholder theory offered a new form of managerial understanding and action (Jonker \& Foster, 2002), a new way to organize thinking about firms' responsibilities by suggesting that the needs of shareholders cannot be met without satisfying the needs of other stakeholders (Foster \& Jonker, 2005, Hawkins, 2006, Jamali, 2008). Maximizing profits and creating value for shareholders can no longer be the sole objectives of management; rather, benefits must be obtained through, or in coexistence with, a grid of values of other stakeholders (Longo, Mura, \& Bonoli, 2005), among which are the demands and needs related to corporate social responsibility practices.

Corporate social responsibility practices form part of a strategic plan by corporations to show a firm's social performance to stakeholders (Roberts, 1992); in other words, we can understand corporate social responsibility practices as a part of the dialogue between the company and its stakeholders (Gray, Kouhy, \& Lavers, 1995, p. 53). These practices include business activities in the public sphere and communicative actions. As to the former, firms finance projects, for example, in public health, education, the environment, and human rights. Regarding communicative activities, companies act according to the Theory of Communicative Action, revealing to the public their actions in affirmation of ethics. They thus attempt to influence public policy through lobbying (Vasconcelos, Alves, Pesqueux, 2012).

According to Agle, Donaldson, Freeman, Jensen, Mitchell, \& Wood, (2008, p. 162) "stakeholder theory and corporate social responsibility cannot offer a complete solution for addressing the problems of business and society; they can, however, point to a need for social controls to encourage the beneficial effects of institutional behaviors and to regulate or prevent the harmful effects".

With respect to the use of stakeholder theory as a conceptual framework for analysis, mention should be made, among others, of the studies by Roberts (1992) and Van der Laan Smith, Adhikari, \& Tondkar (2005) for the individual analysis of firms at a national and international level, respectively.

In the present study we also resort to institutional theory as part of our framework, since it has been used to explain the homogeneity of organizations that operate in the same business environment (Dimaggio \& Powell, 1983). Under institutional theory, it is argued that firms respond to external pressure from their respective stakeholders regarding corporate social responsibility practices by mimicking larger firms' reporting. They do so in order to maintain their state of legitimacy to continue operating within the business environment (Aerts, Cormier, \& Magnan, 2006).

Institutional theory has been developed since the 1970 s within organizational theory, by authors such as Dimaggio \& Powell (1983), who wondered why there was such a high degree of similarity between organizations.

These same authors state that, "we ask why there is such startling homogeneity of organizational forms and practices 
and we seek to explain homogeneity, not variation. In the initial stages of their life cycle, organizational fields display considerable diversity in approach and forms. Once disparate organizations in the same line of business are structured into an actual field (by competition, the state or the professions) powerful forces emerge that lead them to become more similar to one another" (Dimaggio \& Powell, 1983, p. 148).

This theory is very important in the field of corporate social responsibility practices and adds a complementary perspective to stakeholder theory in seeking to comprehend how organizations understand and respond to changing social and institutional pressures and expectations (Deegan and Unerman, 2011).

These social changes and institutional pressures are the result of economic, sociopolitical and institutional conditions, as indicated by Campbell (2007). This same author considers firm profitability within these conditions: competition, regulations imposed by the State, and a firm's own regulatory mechanisms to ensure fair practices, product quality or workplace safety and institutionalized dialogue with unions, employees, community groups, investors and other stakeholders.

The truth is that although debate has raged throughout the literature about what theories should be applied in the field of corporate social responsibility, and even today several different authors do not agree, according to a study performed by MIT Sloan Management Review and The Boston Consulting Group, $70 \%$ of executives surveyed from companies located in different countries believe it is necessary to implement strategies for corporate social responsibility in the organization in order to be more competitive. In fact, $68 \%$ say they have increased their social responsibility practices in the last year.

Companies argue that integrating corporate social responsibility practices into the core of their activity and addressing social and environmental issues helps them improve their reputation and their level of recognition, which suggests more profit in the long term. Furthermore, and most important, they believe that corporate social responsibility is an important factor in overcoming the economic crisis and in regaining the confidence that companies and institutions have lost.

\section{Corporate social responsibility practices in Brazil}

In light of the situation described above, it is not surprising that practices of corporate social responsibility are becoming more common in companies, and this trend extends to Brazil as well. According to Griesse, (2007); Scharf, (2009); Young, (2004), Brazil has had a positive experience in social and responsibility programs because of its long tradition of philanthropy. This was reflected in a census conducted in 2005 by the Group of Institutes, Foundations and Companies (GIFE), which found that the 101 member companies invested about US\$555 million in philanthropic initiatives that constitute approximately $25 \%$ of the money invested by the private sector designated to foundations and non-profit organizations in Brazil (Scharf, 2009).

The importance of philanthropy in Brazilian society can be considered to have derived from the social inequalities that have historically characterized the country. Young (2004, p. 292) believes that in Brazil there are great opportunities that coexist with large inequalities and these problems are rooted in the history of this nation (Griesse, 2007).

Although these philanthropic characteristics are of great relevance in Brazilian society, in the past couple of decades, individual actions have gradually been replaced by a corporate framework of social responsibility that is more formalized. It is intended to implement programs that go beyond short-term social actions, and according to Duarte (2010), Brazil has been the leading country in corporate social responsibility with more than half of the ISO 14.001 environmental certifications in Latin America and even more certifications of the SA 8000 regarding labor issues, more than any other country in America. Also to be highlighted in the case of Brazil is the great importance of the Third Sector as a space favorable to the influence of companies through corporate social responsibility activities (Alves, 2004).

Brazilian companies are also pioneers among the countries of Latin America in the publication of corporate social responsibility practices in sustainability reports in accordance with the Global Reporting Initiative (GRI). A study by Haslam (2004) shows that Brazilian companies could be considered a special case in corporate social responsibility issues now that companies reflect their commitment to CSR and present their reports closer to Canadian standards than to those of Latin America.

Thus, as explained previously, corporate social responsibility practices are increasingly being considered by Brazilian companies. Duarte (2010) corroborates this in an exploratory study conducted on five executives at large Brazilian companies. These managers believe that personal values play an important role in the development and maintenance of social and environmental practices carried out by Brazilian companies.

According to Griesse (2007), in Brazil, geographical conditions influence the cultural values of communities, workers, consumers, business people, and professionals. They also influence the way government is run. Thus the intersections of geography with economic, political, and sociological factors form a mosaic of conditions in which people live and work. The Brazilian Institute of Geography and Statistics has somewhat arbi- 
trarily classified the Brazilian territory into five major regions: South, Southeast, Central-West or Midwestern, Northeast, and North. These divisions reflect the diversity of resources and conditions available for economic and social development.

Griesse (2007) states that the South is known for its agricultural development and also its model quality-of-life. The Southeast is the most industrialized and technologically advanced region of Brazil. The Central-West is economically the fastest-growing region of Brazil given the vast areas of land available for agriculture and cattle-raising. The Northeast is one of the poorest regions of Brazil. Most of the states can be divided into the fertile coastal region and the drought-plagued sertão or caatinga area. The North includes the Amazon Basin and is the least populated but is home to most of the Amerindian peoples. Explorations for minerals, rubber, and timber there have been met with criticism by environmentalists (Griesse, 2007).

In a larger study with a sample of 500 companies from different sectors of activity, the Instituto Ethos (2008) has developed a questionnaire on corporate social responsibility practices carried out by small, medium and large companies; this questionnaire includes items related to values, transparency and corporate governance, the internal public, the environment, suppliers, consumers and customers, community, government and society.

\section{RESEARCH METHOD}

\section{Population and sample}

The sample of Brazilian companies chosen comprises 500 companies grouped by geographical areas in 2008 , the latest year for which information is available. Information regarding firm size, activity sector, and the number of firms per region is presented in Table 1.

TABLE 1. Descriptive analysis of the sample

\begin{tabular}{l|l|l|l|l|l}
\hline \multicolumn{6}{l}{ Descriptive Analysis of the Sample (2008) } \\
\hline Sector & $\%$ & Firm size & $\%$ & Firms by region & $\%$ \\
\hline Industry & 6 & Small & 83 & North & 7 \\
\hline Commerce & 39 & Medium & 9 & Northeast & 17 \\
\hline Others* & 55 & Large & 8 & Midwestern & 13 \\
\hline & & & & South & 39 \\
\hline & & & & Southeast & 24 \\
\hline Total & 100 & & 100 & & 100 \\
\hline
\end{tabular}

* Services, agricultural products
The methodology employed by the Instituto Ethos (2008) for data collection was a questionnaire applied to individual firms, although the published data provided are aggregated and grouped by geographical location.

The questionnaire contains three types of questions: "indepth questions" addressed to assessing the company's management with respect to a specific practice; binary (yes/no) questions that qualify the answer chosen for the in-depth questions and that confirm and seek additional details regarding the corporate social responsibility stage identified by the company. They also contribute to the comprehension of practices that should be incorporated into the company's business management. Binary items must be answered unless the topic of the corresponding in-depth indicator does not apply to the company being surveyed. Finally, there are quantitative items, although some of the indicators do not involve quantitative data (Instituto Ethos, 2008).

In this study, the practices of corporate social responsibility provided by the Instituto Ethos (2008) have been grouped into four categories: the first group's practices performed by Brazilian companies in relation to labor practices and decent work, such as employment, diversity and equal opportunity, training and education and human rights (non-discrimination, freedom of association, indigenous rights, and avoiding child labor, as well as forced and compulsory labor). These are represented in this study by the abbreviation PS.

Another group of practices addresses product responsibility (abbreviated here as PRP). This includes those aspects of a reporting organization's products and services that directly affect customers: health and safety, information and labeling, marketing, and privacy.

Environmental practices are also considered in this study (abbreviated as PM). These practices concern material, energy, water, emissions, effluents, waste, biodiversity and environmental compliance.

Finally, we have the category that represents the impact that organizations have on the communities in which they operate (PC), such as the risks associated with bribery and corruption, undue influence on public policy-making, and monopoly practices.

It is important to emphasize that this classification was drawn up according to the proposals of the GLOBAL REPORTING INITIATIVE (2011), the means most widely used in the world by firms to disseminate their CSR practices (Kpmg, 2008). For all the CSR practices grouped by PS, PRP, PM and PC, see Exhibit 1.

At the same time, companies are grouped by the geographical areas of Brazil corresponding to the north, northeast, mid-west, southeast and south. 


\section{Exhibit 1. CSR practices undertaken by Brazilian companies according to the Instituto Ethos}

PS1 Provides independence for unions to act in the workplace

PS2 Meets periodically with the union to hear suggestions and negotiate demands

PS3 Maintains programs to promote ethnic, gender and religious diversity within the company

PS4 Has recruitment programs, training programs and incentivizes the promotion of women, African Americans and disabled people, seeking to promote equal opportunities

PS5 Has clear goals to reduce the gender and race inequalities and to avoid differences in wages and benefits for people with a disability.

PS6 Does not use and demand in contract the same commitment from the entire chain of value (suppliers, distributors, customers, etc...)

PS7 They are not used and programs are developed to eliminate them throughout the entire chain of value.

PS8 Maintains literacy programs, personal development, cultural or professional capacitation programs

PS9 Maintains continuing education programs and support in the development of new skills, not restricted only to the functions performed by the employee.

PS10 The company provides the employees with a salary that ensures an adequate standard of living for themselves and their families.

PS11 Compensation policies, benefits, and career development are formalized and disclosed to employees

PS12 Have rules and procedures aimed at preventing moral and sexual harassment

PS13 Guarantees to an outsourced employee the same health and safety conditions in a work environment and access to basic benefits enjoyed by regular employees, such as transportation, food, child care, clinical care etc...

PRP1 Adopts measures regarding its products and/or services that aim to minimize risks to the health and safety of the consumer or customer

PRP2 Ensures that all the products and / or services offered meet the standards of consumer or customer safety and health protection

$\mathrm{PRP}_{3}$ The company offers information about health and safety and other relevant specifications about their products and / or services to the consumer or customer so that they can make their own choice.

PRP4 The information offered by the company to the customer or consumer includes the precautions to be observed in both the use and disposal of its products or services.

$\mathrm{PRP}_{5}$ It offers the consumer or customer information about its relationship with employees, community, suppliers and government

PRP6 Informs the consumer about the environmental and social impacts caused by their production processes and their products and services.

PRP7 Promotes information programs and consumer education about the social and environmental impacts related to their consumption habits at home, at work, shopping, transportation, leisure etc.

PRP8 Develops educational campaigns encouraging their employees to choose products or services according to the social responsibility of manufacturers.

PRP9 It has an after-sales relationship system with its customers or consumers

PRP10 Only uses data recorded from its clients or consumers with their prior authorization.

PM1 Discusses with its suppliers the environmental impacts caused by obtaining raw materials for their products or services and the production process, encouraging them to reduce them.

PM2 Adopts measures to reduce environmental impacts from production, distribution and consumption of their products and services.

$\mathrm{PM}_{3}$ Maintains programs for rationalization and optimization of energy use

PM4 Maintains programs for rationalization and optimization of water use

PM5 Maintains a selective waste program for non-industrial waste.

PM6 Maintains a specific program to reduce emissions

PM7 Does the inventory of emissions 


\section{(Cont.) Exhibit 1. CSR practices undertaken by Brazilian companies according to the Instituto Ethos}

PM8 Invests in new technologies to increase the durability of its products

PMg Invests in new technologies to enable the recycling of its products after use

PM10 Invests in new technologies to allow a cleaner production process

PM11 Invests in the improvement of packaging, substituting certain raw materials that are less harmful to the environment.

PC1 Have formal criteria to define their financing or support for candidates for public office

PC2 Publishes every election the amount of their contributions to political campaigns

PC3 Formally participates in initiatives that are against corruption in all of its forms (bribery, tax evasion, fraud and other), for example, the Global Compact and the Business Pact for Integrity and against Corruption.

PC4 Strongly emphasizes to the internal public its prohibition of the practice of corruption or bribery, even if used for the benefit of the company

PC5 Adopts anti-corruption and anti-bribery practices in its processes of buying and selling.

PC6 Maintains or supports environmental projects in its community or in the country, through financial support and / or the contribution of its technical, technological and managerial support.

PC7 Defines funds in its budget for environmental projects which it supports

PC8 Actively encourages the associations or business entities in which it participates to mobilize themselves when there are propositions of public interest.

PC9 Identifies and assesses the impacts of their activities in nearby communities

PC10 Systematically includes individuals or groups from the surrounding community among its suppliers, such as neighborhood associations and cooperatives.

PC11 Stimulates the volunteer work of its employees in environmental projects for the benefit of nearby communities or society

\section{Analysis technique}

The technique chosen to conduct this research is the biplot by Gabriel (1971). This technique consists of the graphic representation of a matrix of data $X(n \times p)$ that results in observing $n$ individuals in $p$ numerical characteristics. In our research the $n$ individuals are the companies grouped in the five geographical areas of Brazil which are: north, northeast, mid-west, southeastern and south, and the numerical characteristics $p$ are the practices of corporate social responsibility implemented by the Brazilian companies listed in Appendix1.

The biplot is a planar or three-dimensional graphical representation, where the "bi" in the word biplot refers to the fact that in this graph there are two types of markers corresponding to two types of information: markers for the individuals or rows and markers for the variables or columns.

The markers are vectors that represent individuals or rows and columns or variables on the plot. Gabriel (1971) does not specify the method in which the biplot markers are obtained, but here we have employed the method of least squares and decomposition into vectors and singular values of X. Gabri- el (1971) proposed that one of the criticisms of the biplot was that while it handles the statistical and geometric properties of the variables well, that is not the case with individuals, who are poorly represented.

Galindo (1985) generalized the concept of simultaneous representation creating a new type of biplot, called the $\mathrm{HJ} \mathrm{Bi-}$ plot, which applies to any set of two-way data and allows it to represent individuals and variables with equal quality of representation, something that does not occur in Gabriel's biplot (1971).

Galindo $(1985,1986)$ defines the HJ Biplot as “a multivariate graphical representation of an Xnxp matrix using markers for its rows and columns, chosen so that both markers may be superimposed on the same reference system with the highest quality of representation".

The interpretation of biplots is based on established authors like Gower \& Hand (1996), who concede that a biplot must consider points to represent individuals (in our research, the companies are grouped by geographical areas) and axes to represent the variables (in our research, the variables representing social practices, product responsibility practices, environmental practices and community-oriented practices). 
The variables represented on a bi-plot are interpreted according to the angle in which the vectors are formed; thus the variables with vectors that form a small angle are variables with similar behavior, individual markers close to one another correspond to similar individuals and individual markers very distant from each other in the graph correspond to individuals that are not similar.

Furthermore, if a small angle exists between an individual and a variable it means that the individual is significant in explaining the variable and that the variable has high a value for the individual.

In other words, the more distant the points representing the characteristics appear to be from the center of gravity, the more variability these characteristics will have shown in the study. Therefore, observing the distance of the variables we obtain the variability of the variables and this gives an idea of the dispersion on the plane. When two variables are close together they are said to be highly correlated and behave similarly; when they are opposite they are highly correlated in a reversed way and if they are perpendicular they are independent.

As for the angles, the smaller the angle formed by the two vectors that join the center of gravity with the points that represent the variables, the more correlated the characteristics are, and finally the co-variation of the variables is obtained by observing the angle.

The software used to apply the HJ Biplot was designed by Vicente-Villardón (2010). It is a program developed for the interpretation of biplots and it contains the classic biplots, $\mathrm{HJ}$ biplots, and correspondence analysis, among other multivariate techniques.

\section{EMPIRICAL ANALYSIS RESULTS}

The results are represented in several tables and graphs obtained by applying the multi-biplot software. Eigenvalues and explained variances are shown in Table 2.

\section{TABLE 2. Eigenvalue and explained variance}

\begin{tabular}{|c|c|c|c|}
\hline Axis & Eigenvalue & Expl. Var \% & Cumulative \% \\
\hline Axis 1 & 9.403 & 49.116 & 49.116 \\
\hline Axis 2 & 6.428 & 22.958 & 72.074 \\
\hline Axis 3 & 5.427 & 16.364 & 88.438 \\
\hline Axis 4 & 4.562 & 11.562 & 100 \\
\hline
\end{tabular}

From the table above it can be inferred that there is a dominant axis that absorbs $49.116 \%$ of the system's total inertia. The trend of eigenvalues is truncated in the third axis (elbow), reach- ing an accumulated inertia of 88.438 . The other factors provide little information and we therefore decided to retain the first 3 factorial axes for classification.

The contribution of the factor to the element, considering the factor as the observable variables that are represented in the data matrix, is as shown in Table 3.

As shown, the variables representing corporate social responsibility practices PS12, PRP8, PM1, PM2, PM6, PM10, PC9 make a strong contribution to axis 1 and contribute little to the remaining axes; the opposite occurs with $\mathrm{PS}_{1}, \mathrm{PS}_{3}, \mathrm{PS} 8, \mathrm{PS}_{11}$, PC6 and PC7, which make the largest contribution to axis 2; and $\mathrm{PS}_{5}, \mathrm{PS}_{7}, \mathrm{PS}_{13}, \mathrm{PC}_{3}, \mathrm{PC}_{11}$ make a greater contribution to axis 3 and a lesser contribution to the rest of the axes.

Regarding the graphical representation, in Figure 1 shows the five geographical zones to which the companies represented in Appendix 1 belong; that is, what we call the individuals on a Biplot.

\section{Figure 1. Geographical Zones}

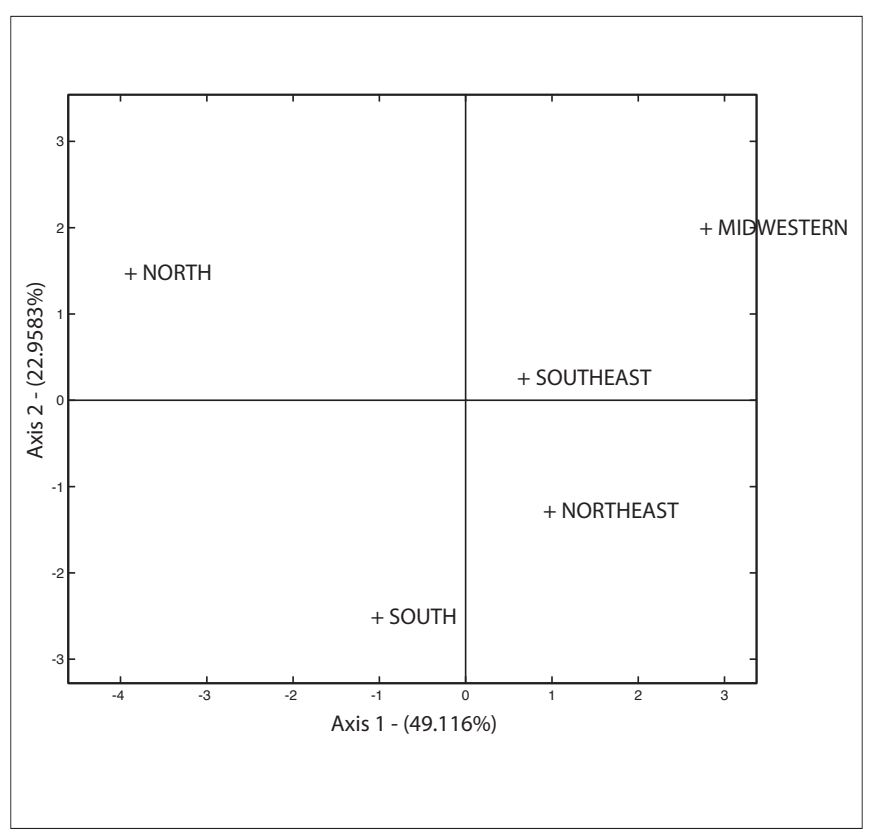

As can be seen in Figure 1 it is possible to infer that all the companies under study in this research are located in 5 geographic areas and are represented by dots (in our case a cross) in four quadrants. Quadrant 1 represents all the companies that are concentrated in the southeast of Brazil; quadrant 2 represents all the companies that are concentrated in the north of the country; quadrant 3 represents the companies that are located in the south of Brazil and quadrant 4 represents the companies whose headquarters are in the northeast of the country. Therefore, it appears there are four distinct areas and conversely there exists a geographical area corresponding to the mid-western companies which is not very well represented in Figure 1. 
TABLE 3. Relative contribution of the factor to the element

\begin{tabular}{|c|c|c|c|}
\hline Variables & Axis 1 & Axis 2 & Axis 3 \\
\hline PS1 & 25 & 607 & 345 \\
\hline PS2 & 694 & 249 & 45 \\
\hline $\mathrm{PS}_{3}$ & 13 & 636 & 0 \\
\hline PS4 & 815 & 115 & 4 \\
\hline $\mathrm{PS}_{5}$ & 236 & 82 & 649 \\
\hline PS6 & 426 & 3 & 408 \\
\hline PS7 & 24 & 54 & 562 \\
\hline PS8 & 145 & 697 & 155 \\
\hline PS9 & 514 & 310 & 145 \\
\hline PS10 & 792 & 179 & 10 \\
\hline PS11 & 82 & 734 & 2 \\
\hline $\mathrm{PS}_{12}$ & 970 & 9 & 4 \\
\hline $\mathrm{PS}_{13}$ & 335 & 83 & 579 \\
\hline PRP1 & 590 & 370 & 14 \\
\hline $\mathrm{PRP}_{2}$ & 790 & 82 & 122 \\
\hline $\mathrm{PRP}_{3}$ & 148 & 9 & 222 \\
\hline $\mathrm{PRP}_{4}$ & 675 & 37 & 282 \\
\hline $\mathrm{PRP}_{5}$ & 511 & 366 & 58 \\
\hline PRP6 & 822 & 3 & 124 \\
\hline PRP7 & 724 & 200 & 73 \\
\hline PRP8 & 937 & 14 & 38 \\
\hline PRP9 & 9 & 258 & 219 \\
\hline PRP10 & 376 & 200 & 362 \\
\hline $\mathrm{PM}_{1}$ & 911 & 7 & 8 \\
\hline $\mathrm{PM} 2$ & 923 & 57 & 18 \\
\hline $\mathrm{PM}_{3}$ & 758 & 2 & 0 \\
\hline $\mathrm{PM}_{4}$ & 147 & 676 & 17 \\
\hline $\mathrm{PM}_{5}$ & 76 & 468 & 339 \\
\hline PM6 & 920 & 18 & 18 \\
\hline PM7 & 689 & 119 & 161 \\
\hline PM8 & 576 & 192 & 55 \\
\hline PM9 & 859 & 0 & 113 \\
\hline PM10 & 916 & 77 & 7 \\
\hline PM11 & 698 & 9 & 223 \\
\hline $\mathrm{PC}_{1}$ & 692 & 160 & 31 \\
\hline $\mathrm{PC} 2$ & 301 & 240 & 148 \\
\hline $\mathrm{PC}_{3}$ & 12 & 386 & 587 \\
\hline $\mathrm{PC}_{4}$ & 382 & 358 & 6 \\
\hline $\mathrm{PC}_{5}$ & 733 & 0 & 230 \\
\hline PC6 & 8 & 870 & 106 \\
\hline $\mathrm{PC}_{7}$ & 132 & 635 & 32 \\
\hline PC8 & 216 & 565 & 28 \\
\hline PC9 & 937 & 3 & 1 \\
\hline $\mathrm{PC} 10$ & 551 & 189 & 13 \\
\hline $\mathrm{PC}_{11}$ & 10 & 1 & 801 \\
\hline
\end{tabular}

As can be observed in Figure 2, the variables reflected correspond to the corporate social responsibility practices of the companies considered in the study: 13 corporate social responsibility practices refer to social aspects, 10 refer to product responsibility, 11 to environmental aspects, and 11 to socially responsible actions of the company towards the community (see Appendix 1).

Continuing with the biplot interpretation, and as previously mentioned in the analysis technique section, the variables represented are interpreted according to the angle formed between the vectors. The variables with vectors forming a small angle are variables with similar behavior; environmental practices such as PM6 and PM11 or PM2 and PM10 have a very small angle and therefore have a similar behavior.

Conversely, individual markers very distant from each other on the graph correspond to individuals that are not similar, as for example $\mathrm{PRP}_{3}$ (represented in quadrant 1) and $\mathrm{PRP}_{5}$ (represented in quadrant 4 ).

In Figure 3, the individuals (the companies grouped by geographical area) and the variables (the corporate social responsibility practices) are reflected jointly.

From the combined interpretation of the individuals and variables, and from the theoretical point of view, if there is a small angle between the individual and a variable it means the individual is significant in explaining the variable and the variable has great value for the individual.

It can thus be observed that the variables corresponding to environmental practices are closer to those companies located in the northern geographical area of Brazil, while the variables representing social practices and practices with the community are closer to companies located in the south and northeastern geographical area of the country. It can also be highlighted that variables related to product responsibility correspond to companies conducting business in the southeast of the country.

The northern region of Brazil has been undergoing major changes in its landscape; industrial activity is poorly developed and the states of this region do not have good infrastructure or adequate social services such as access to education, health, safety, employment and transport. Engaging and occupying land without planning and the absence of state government has contributed to a profound impact on the environment, in which the main factors of devastation are the following: wood extraction, mineral extraction (as in mining), and in particular the increasing expansion of agricultural and pastoral areas (Freitas, 2012). The ecosystem is characterized by the presence of the Amazon rainforest in all the states of this region, with an enormous variety of trees, plants, mam- 
mals, birds and fish. The main environmental problems of the region are related to the advancement of deforestation and fires in the last few decades, where about $80 \%$ of the wood removed from the Amazon rainforest is done through illegal means, causing a major environmental impact. This is perhaps a possible explanation for the reason why the northern region is concentrating on a larger number of social responsibility practices relating to the environment.

\section{Figure 2. Representation of variables}

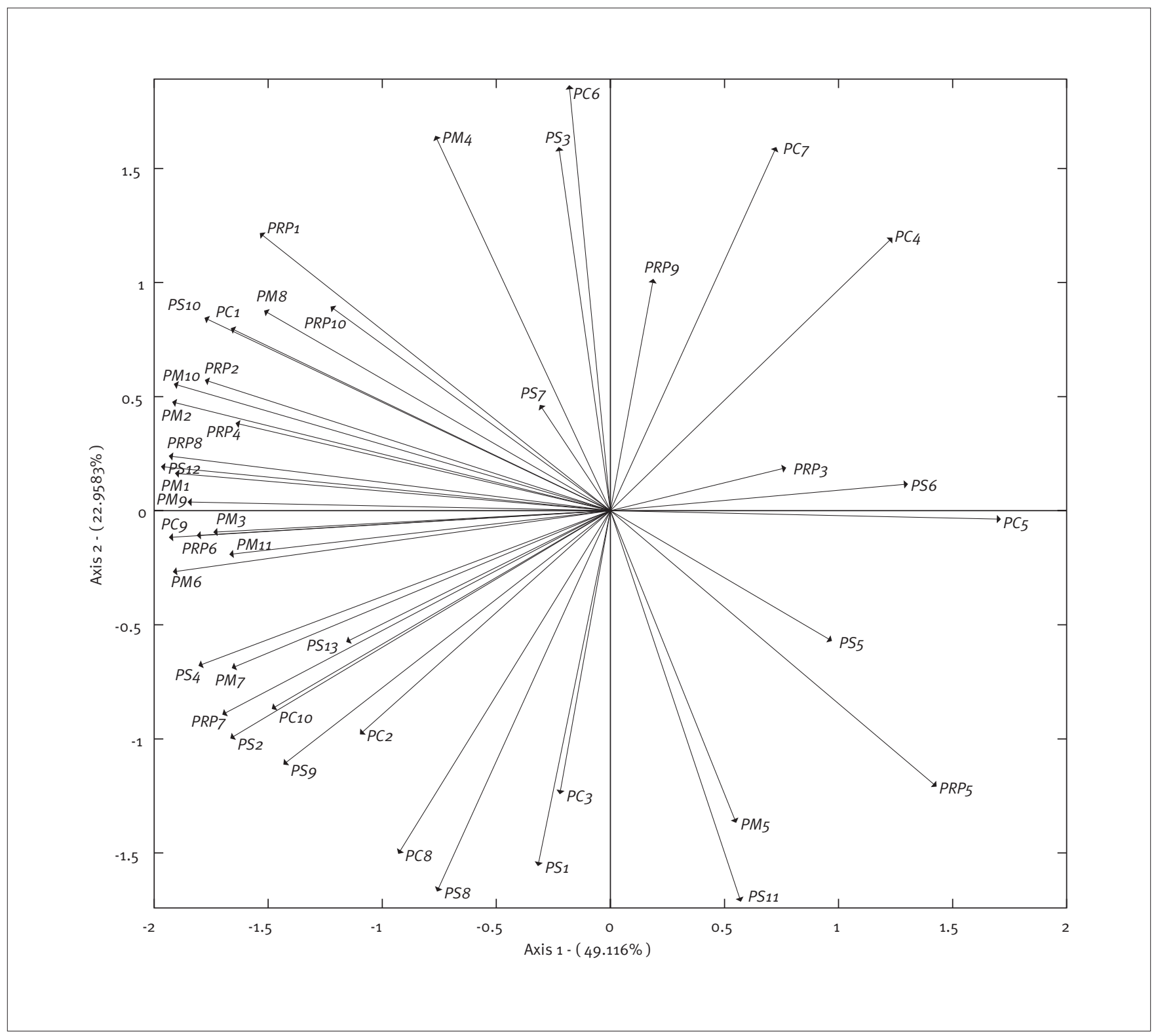

The northeast region was one of the most exploited during the colonial period, when slave labor was used, and thus these colonial factors generated a legacy marked by structural and economic problems. Large areas of land predominately lay in the hands of only a few owners, the elite of their time, who contributed to elevated social inequalities (Freitas, 2012). The northeastern region has one of the most serious social situations of the country due to the population density in some areas and to the crisis in some of the traditional sectors, such as sugar cane for the production of alcohol and cacao; the cyclical problem of drought, and its extension (Portal Brasil, 2012). This situation entails complex social issues that may explain why companies operating in the northeastern part of Brazil are more concerned with social practices towards the community. 
Figure 3. Geographical areas and variables

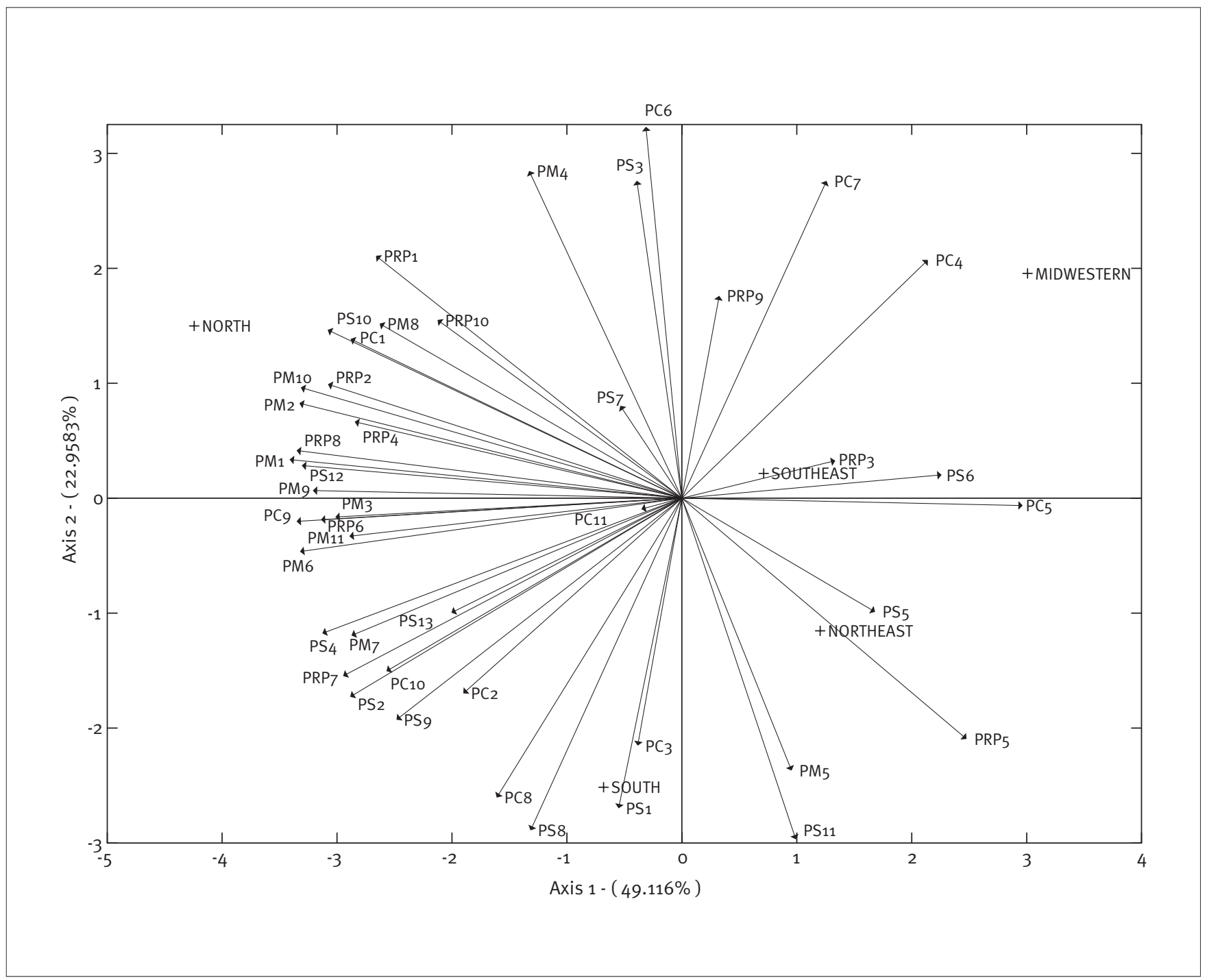

The development of Brazil's domestic industry during the $20^{\text {th }}$ century took place mainly in the southeast, with a resulting economic concentration (Siqueira \& Siffert, 2001). Its economy is the most developed and industrialized of the five Brazilian regional economies, concentrating more than half of national production and driven by the major manufacturers and steel working plants in the country (Portal Brasil, 2012). In view of the economic development of the southeast region it is expected that companies there will be greatly concerned with their resulting products and/or services; therefore, their corporate social responsibility practices are geared towards products and services.

In order to analyze the possible different groupings of corporate social responsibility practices in relation to the different geographic areas, we performed a cluster analysis. By apply- ing this criterion it is possible to identify which variables are responsible for the different groups.

The methodology used for this cluster analysis is hierarchical clustering with Euclidean distance using biplot scores and the ward test with three groups of clusters (see Figure 4 ).

Figure 4 shows three clusters: cluster 1 , consisting of firms located in the geographical area of southern Brazil, cluster 2, which includes the northeast, southeast, and mid-western area, and cluster 3, which includes the northern area of the country. Also, by observing Table 4 it is possible to infer where each of the clusters is positioned according to statistical analysis and corresponding to what is represented in Figure 4.

From the dendrogram shown in Figure 5 , it is also possible to infer this same classification of clusters. 
Figure 4. Cluster representation

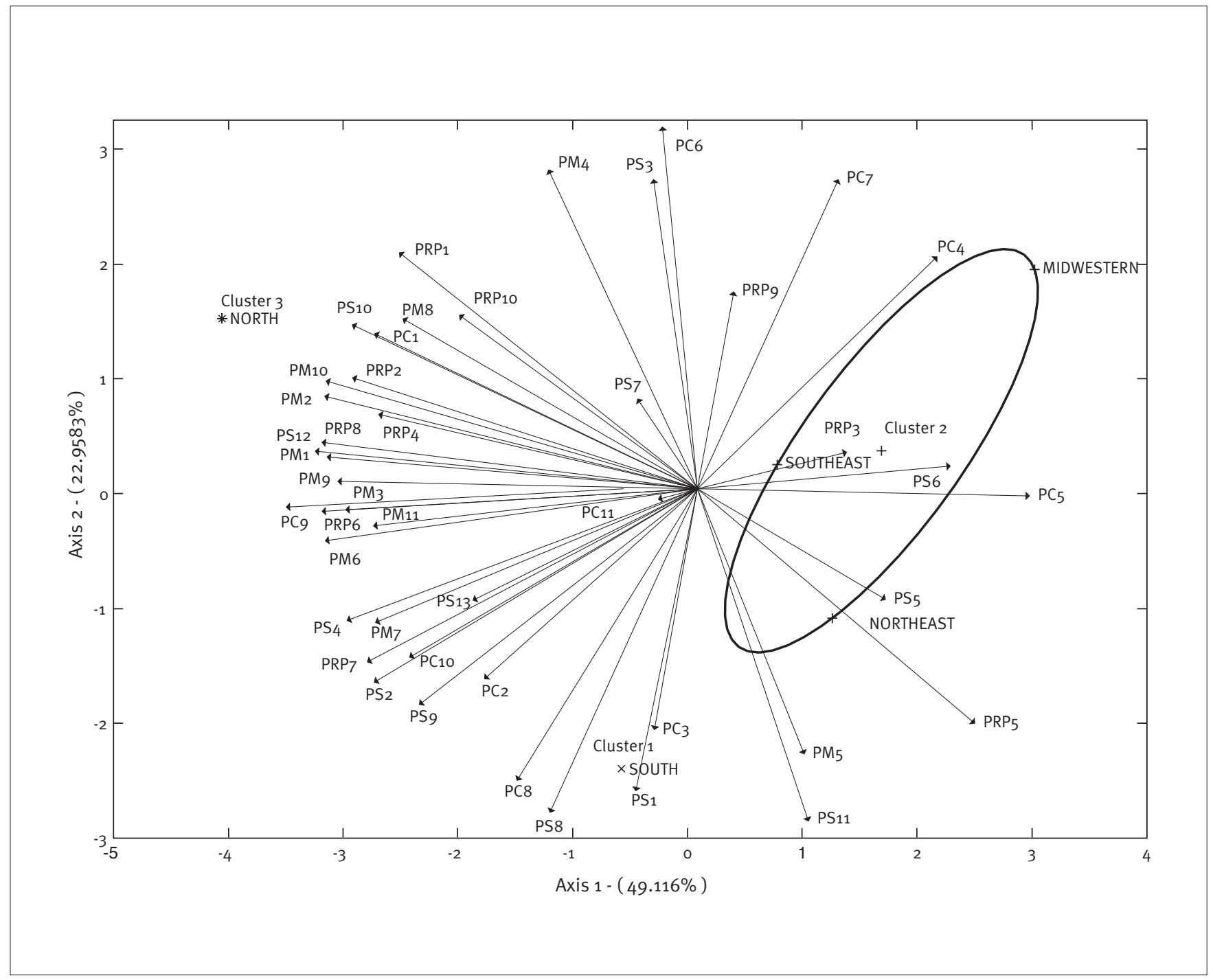

TABLE 4. Number and position of clusters

\begin{tabular}{l|l}
\hline & Cluster \\
\hline North & 3 \\
\hline Northeast & 2 \\
\hline Midwest & 2 \\
\hline Southeast & 2 \\
\hline
\end{tabular}

Figure 5. Dendrogram

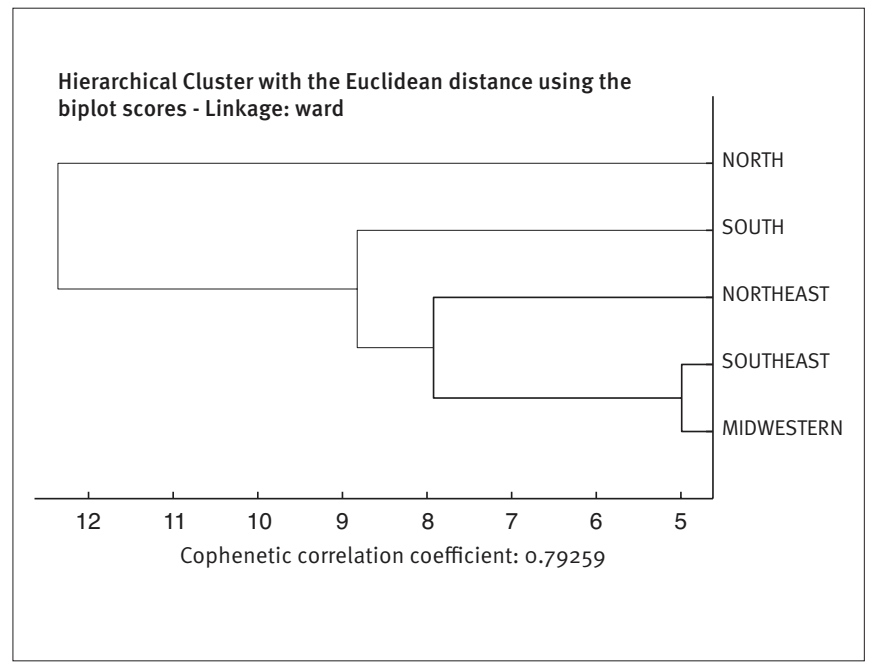


In the dendrogram, it is possible to observe a cophenetic correlation coefficient of 0.79259 , which is very good since the closer to 1 the value is, the better. We also obtained 3 clusters, thus corroborating the earlier analysis as stated; the clusters are formed by the companies located in southern Brazil, companies in northern Brazil and companies located in the northeast, southeast and mid-western part of Brazil.

One of the main advantages of this method consists in determining which variables are responsible for the configuration of the different clusters. Thus, the idea is to determine the configuration the clusters have on the different factorial planes, especially when analyzing the relative contributions of the factor to those elements of the variables that have the greatest impact on the formation of clusters.

If we analyze Cluster 1 in the factorial planes, we obtain the results shown in Table 5 .

\section{TABLE 5. Analysis of the first cluster}

\begin{tabular}{l|l|l}
\hline Geographical area & Plane 1-2 & Plane 1-3 \\
\hline \multirow{3}{*}{ South } & $P S_{1}$ & $P S_{1}$ \\
& $\mathrm{PC}_{3}$ & $\mathrm{PC}_{3}$ \\
\hline
\end{tabular}

The geographical area of cluster 1 in plane 1-2 corresponds to the firms located in southern Brazil, PS1 being the most important variable, referring to the independent practices of trade union operations in a workplace, the quality of representation being 632 , and $\mathrm{PC}_{3}$ refers to the efforts the company has engaged in to combat corruption in every aspect and form such as bribery, fraud and others, the quality of representation being 398

If we analyze Cluster 2 in the factorial planes, we obtain the results shown in Table 6 .

\section{TABLE 6. Analysis of the second cluster}

\begin{tabular}{l|l|l}
\hline Geographical area & Plane 1-2 & Plane 1-3 \\
\hline & & \\
Southeast & $\mathrm{PS6}$ & $\mathrm{PC} 7$ \\
Midwest & $\mathrm{PS}_{5}$ & $\mathrm{PRP}_{5}$ \\
Northeast & $\mathrm{PRP}_{3}$ & $\mathrm{PRP}_{3}$ \\
& & \\
\hline
\end{tabular}

The geographical area of cluster 2 in plane 1-2 corresponds to the firms located in the southeast, mid-west and northeast of Brazil, the most important variables being PS6, regarding the requirement of the same commitment throughout the whole value chain (suppliers, customers and distributors), the quality of representation being 429; PS5, whose objective is to reduce gender and race inequality, and avoid wage differ- ences in relation to individuals with disabilities, 318 being the quality of representation; and $\mathrm{PRP}_{3}$, in which the company offers health information, security and other relevant specifications about their products and services for the consumer or customer with a quality of representation of 157.

If we analyze Cluster 3 in the factorial planes we obtain the following results, as shown in Table 7.

\section{TABLE 7. Analysis of the third cluster}

\begin{tabular}{l|l|l}
\hline Geographical area & Plane 1-2 & Plane 1-3 \\
\hline & PM10 & PM3 \\
North & PM2 & PC9 \\
& PS10 & PS4 \\
\hline
\end{tabular}

The geographical area of cluster 3 in plane 1-2 corresponds to the firms located in northern Brazil, and the most important variables are $\mathrm{PM} 10$, which refers to investment in new technologies for a cleaner production process, the quality of representation being 993; PM2, in which the objective is to take action to reduce environmental impacts regarding production, distribution and consumption of products and services, the quality of representation being 980 ; and PS10, to provide workers with remuneration that ensures an adequate standard of living for themselves and their families, the quality of representation here being 971.

\section{DISCUSSION AND CONCLUSIONS}

According to the interpretation of biplots based on established authors such as Gower \& Hand (1996), a biplot must consider points to represent individuals (in this study, companies grouped into 5 geographical areas) and axes to represent the variables in question (in our research, corporate social responsibility practices carried out by Brazilian companies).

In this study, we assessed whether the corporate social responsibility practices of 500 companies grouped into 5 geographical areas were the same or if conversely there were differences depending on the geographic area to which the companies belong.

From the results obtained it can be inferred that the variables corresponding to environmental practices are closer to companies located within the geographical area of northern Brazil, whereas other variables representing social practices with the community are carried out by companies from the south and northeast of the country. Most outstanding is the relation between product responsibility and companies that conduct their business in the southeastern area of Brazil. 
These findings are in accordance with the dual theoretical approach taken. On the one hand, from the perspective of stakeholder theory, we found that the firms in each geographic area carry out different CSR practices owing to the different stakeholder demands and pressures in each region.

At the same time, out findings are also in line with institutional theory, particularly under the perspective of mimetic isomorphism, which occurs when organizations imitate the actions of the most successful ones in the institutional environment. Here we found a convergence of corporate social responsibility practices within geographical regions. This is most likely because social pressures create uncertainty, and thus firms tend to mimic the activities of local rivals in order to reduce uncertainty and gain legitimacy (Fligstein, 1991). This is the case of environmental practices such as PM2 and PM10, which have a very small angle between them and therefore demonstrate similar behavior. They are practices implemented by firms located in the northern geographical area of Brazil. Another example would be the variables representing social practices and practices within the community $\mathrm{PC}_{3}$ and $P S_{1}$ ), which are closer to the companies located in the southern and northeastern geographical areas of the country.

In regard to mimetic isomorphism, several prior research studies have shown that institutional constraints, such as country, industry concentration, size of company and media exposure, affect mimetic corporate social responsibility practices (Aerts, Cormier \& Magnan, 2006, Cormier \& Magnan, 1999, Cormier, Magnan, \& Van Velthoven, 2005, Neu, Warsame, \& Pedwell, 1998). The size of the organization is directly linked to the pressure to provide information (Daub, 2007); Dimaggio \& Powell, 1983) and this characteristic has been used to predict mimetic tendencies (Deephouse, 1996; Westphal, Seidel, \& Stewart, 2001).

A useful example in another area of knowledge is Greenwood, Suddaby \& Hinnings (2002) study about the change in accounting firm services over a 20 year period. They found that the shift from primary service provision of accounting, tax and audits, to the inclusion of services such as financial advice, management consulting and legal services, stemmed from initial mimetic pressures where the largest firms moved earliest and most efficiently in order to serve large clients (Rose \& Hinings, 1999).

Three clusters were obtained from the cluster analysis performed, representing each of the geographical areas: the northern area (cluster 3) in which companies are more likely to implement practices related to environmental issues; the southern area (cluster 1), where companies maintain practices related to social aspects and also towards the community, and the southeast, mid-western and northeast areas (cluster 2), which, like the companies in the south, show practices related to social aspects and to the community but also practices related to product responsibility.
The findings of this research are therefore in consonance with the reality of the Brazilian economy. Brazil is a continental country divided into five regions with different economic and geographic characteristics, whose current state of development can be explained not only by its natural features, but also notably by its historical evolution in the political-economic scenario.

This five-region classification was also made by Griesse (2007), who established that this division reflects the diversity of resources and conditions available for the social and economic development of the country.

For this same author the South is known for its agricultural development and also its model quality-of-life. The Southeast is the most industrialized and technologically advanced region of Brazil. The Midwest is economically the fastest-growing region of Brazil given the vast areas of land available for agriculture and cattle-raising. The Northeast, however, is one of the poorest regions of Brazil. Most of the states can be divided into the fertile coastal region and the drought-plagued sertão or caatinga area. The North includes the Amazon Basin and is the least populated region, but is home to most of the Amerindian peoples. Explorations for minerals, rubber, and timber have been met with criticism by environmentalists, particularly owing to the problem of deforestation caused by cattle breeding, forestry, projects, mineral exploration and hydroelectric projects. The environmental situation of this area continues to be of great concern because deforestation remains unregulated (Griesse, 2007, pp. 33-34).

From all of the above we have been able to deduce the important CSR issues that are of concern to Brazilian society, and how they differ according to geographical area. These are confirmed by the biplot and cluster analysis applied in the present study, adding greater validity to the findings.

At the same time, the results obtained highlight how important it is for Brazilian companies to make known their corporate social responsibility practices. Brazilian companies would thus be applying political and social theories so that the public can access this information on corporate social responsibility practices.

As to the limitations of this research it can be argued that the available information was taken from aggregated data of companies grouped by geographical areas. In future research, it would be desirable to have the individual data of each company in order to learn in more detail the corporate social responsibility practices implemented by individual companies.

As a future line of study this kind of research could be extended to companies of other countries, in an attempt to verify the existence of their practices and compare their possible similarities and differences with the practices followed by the companies observed here. 


\section{NOTE OF APPRECIATION}

The authors thank the Instituto Ethos of Sao Paulo for the data provided to conduct this research, as well as the Ministry of Education, Culture and Sport for the support granted within the framework agreement between Spain and Brazil project EDU/1510/2011 and project CAPES/ DGU 270/12.

\section{REFERENCES}

Aerts, W., Cormier, D., \& Magnan, M. (2006). Intra-industry imitation in corporate environmental reporting: an international perspective. Journal of Accounting and Public Policy, 25 (3), 199-331.

Agle, B. R., Donaldson, T., Freeman, R. E., Jensen, M. C., Mitchell, R. K., \& Wood, D. (2008). Dialogue: toward superior stakeholder theory. Business Ethics Quarterly, 18, 153-190.

Alves, M. A. (2004) O conceito de sociedade civil: em busca de uma repolitização. Organização \& Sociedade, 11 (30), 141-154.

Barin-Cruz, L., \& Boehe, D.M. (2010). How do leading retail MNCs leverage CSR globally? Insights from Brazil. Journal of Business Ethics, 91 (2), 243-263.

Campbell, J. (2007). Why would corporations behave in socially responsible ways? An institutional theory of corporate social responsibility. Academy of Management Review, 32 (3), 946-967.

Casanova, L., \& Dumas, A. (2010). Corporate social responsibility and Latin American multinationals: is poverty a business issue? Universia Business Review, 25, (primer cuatrimestre), 132-145.

Cormier, D, \& Magnan, M. (1999). Corporate environmental disclosure strategies: determinants, costs and benefits. Journal of Accounting, Auditing and Finance, 14 (4), 429-451.

Cormier, D., Magnan, M, \& Van Velthoven, B. (2005). Environmental disclosure quality in large German companies: economic incentives, public pressures or institutional conditions? European Accounting Review, 14 (1), 3-39.

Correa, E., Flynn, S., \& Amit, A. (2004). Responsabilidad social corporativa en América Latina: una visón empresarial. Serie medioambiente y desarrollo, n. 85, 2004. Retrieved from: http://www.eclac.org/publicaciones/xml/4/14904/Icl2104.pdf.

Daub, C. H. (2007). Assessing the quality of sustainability reporting: an alternative methodological approach. Journal of Cleaner Production, 15 (1), $75-85$.

Deegan, C. (2002). The legitimising effect of social and environmental disclosures - a theoretical foundation. Accounting, Auditing and Accountability Journal, 15 (3), 282-311.

Deegan, C, \& Unerman, J. (2011). Financial accounting theory. London: McGraw-Hill

Deephouse, D. L. (1996). Does isomorphism legitimate? The Academy of Management Journal, 39 (4), 1024-1039.

Dimaggio, P. J., \& Powell, W. (1983). The iron cage revisited: institutional isomorphism and collective rationality in organizational fields. American Sociological Review, 48 (2), 147-160.
Donaldson, T, \& Preston, L. (1995). The stakeholder theory of the corporation: concepts, evidence, and implications. Academy of Management Review, 20 (1), 65-91.

Duarte, F. (2010). Working with corporate social responsibility in Brazilian companies: the role of managers' values in the maintenance of CSR cultures. Journal of Business Ethics, 96 (3), 355-368.

Fligstein, N. (1991). The structural transformation of American industry: an institutional account of the causes of diversification in the largest firms: 1919-1979. In W.W. Powwell, \& P.J. DiMaggio (Eds.). The new institutionalism in organizational analysis. Chicago: University of Chicago Press.

Foster, D., \& Jonker, J. (2005). Stakeholder relationship: the dialogue of engagement. Corporate Governance, 5 (5), 51-57.

Freeman, R. E. (1984). Strategic management: a stakeholder perspective. Englewood Cliffs, NJ: Prentice Hall.

Freitas, E. (2012). As economias regionais brasileiras. Available at http://www.mundoeducacao.com.br/geografia/as-economias-regionais-brasileiras.htm.

Gabriel, K. R. (1971). The biplot graphic display of matrices with applications to principal components analysis. Biometrika, 58 (3), 453-467.

Galindo, M. P. (1986). Una alternativa de representación simultánea: HJ Biplot. Qüestiió -Quaderns d'estadística i investigació operativa, 10 (1), 13-23.

Galindo, M. P. (1985). Contribuciones a la representación simultanea de datos multidimensionales. Doctoral Thesis, University of Salamanca.

Global Reporting Initiative. (2011) The G3.1 Guidelines. Retrieved from: https://www.globalreporting.org/reporting/G3andG3-1/g3-1-guidelines/Pages/default.aspx.

Gower, J. C., \& Hand, D. J. (1996). Biplots. London: Chapman and Hall.

Gray, R., Owen, D, \& Adams, C. (1996). Accounting and accountability: changes and challenges in corporate social environmental reporting. London: Prentice-Hall.

Gray, R. H., Kouhy, R., \& Lavers, S. (1995). Constructing a research database of social and environmental reporting by UK companies. Accounting, Auditing and Accountability Journal, 8 (2), 78-101.

Greenwood, R., Suddaby, R., \& Hinings, C. R. (2002). Theorizing change: the role of professional associations in the transformation of institutionalized fields. Academy of Management Journal, 45 (1), 58-80.

Griesse, M. A. (2007). Caterpillar's interactions with Piracicaba, Brazil: a community-based analysis of CSR. Journal of Business Ethics, 73 (1), 39-51.

Haslam, P. A. (2004). The corporate social responsibility system in Latin America and the Caribbean. Canadian Foundation for the Americas (FOCAL). Available at http://commdev.org/files/1469_file_csr_04.pdf.

Hawkins, D. (2006). Corporate social responsibility: balancing tomorrow's sustainability and today's profitability. New York: Palgrave Macmillan.

Instituto Ethos. (2008). Pesquisa, práticas e perspectiva da responsabilidade social empresarial no Brasil. Retrieved from: http://www3.ethos. org.br/.

Jamali, D. (2008). A stakeholder approach to corporate social responsibility: a fresh perspective into theory and practice. Journal of Business Ethics, 82 (1), 213-231.

Jones, T. (1995). Instrumental stakeholder theory: a synthesis of ethics and economics. The Academy of Management Review, 20 (2), 404-437. 
Jonker, J., \& Foster, D. (2002). Stakeholder excellence? Framing the evolution and complexity of a stakeholder perspective of the firm. Corporate Social Responsibility and Environmental Management, 9 (4), 187-195.

Kpmg. Kpmg International Survey of Corporate Responsibility Report. (2008). Retrieved from: http://www.kpmg.com/EU/en/Documents/ KPMG_International_survey_Corporate_responsibility_Survey_Reporting_2008.pdf.

Longo, M., Mura, M \& Bonoli, A. (2005). Corporate social responsibility and corporate performance: the case of Italian SMEs. Corporate Governance, 5 (4), 28-42.

Neu, D., Warsame, H, \& Pedwell, K. (1998). Managing public impressions: environmental disclosures in annual reports. Accounting, Organizations and Society, 23 (3), 265-282.

Portal Brasil. (2012). Brasil - Região Sudeste. Retrieved from: http:// www.portalbrasil.net/regiao_sudeste.htm.

Roberts, R. W. (1992). Determinants of corporate social responsibility disclosure: an application of stakeholder theory. Accounting, Organizations and Society, 17 (6), p. 595-612.

Rose, T, \& Hinings, G. R. (1999). Global clients demands driving change in global business advisory firms. In M. Brock, M. Powell G. R. Hinings (Eds.), Restructuring the professional organization, 41-67. London: Routledge.
Scharf, R. (2009). Why Brazil leads the region in CSR. Americas Quarterly, 2 (1), 68. Retrieved from: http://www.americasquarterly.org/node/288.

Siqueira, T, \& Siffert, N. (2001). Desenvolvimento Regional do Brasil: tendências e novas perspectivas. Revista do BNDES, Rio de Janeiro, 8, (16), 79-118. Retrieved from:http://www.bndes.gov.br/SiteBNDES/export/sites/default/bndes_pt/Galerias/Arquivos/conhecimento/revista/rev1603.pdf.

Van Der Laan Smith, J, Adhikari, A, \& Tondkar, R. H. (2005). Exploring differences in social disclosures internationally: a stakeholder perspective. Journal of Accounting and Public Policy, 24 (2), 123-151.

Vasconcelos, I, Alves, M, \& Pesqueux, Y. (2012). Responsabilidade social corporativa e desenvolvimento sustentável: olhares habermasianos. RAE-Revista de Administração de Empresas, 52 (2), 148-152.

Vicente-Villardón, J. L. (2010). A package for multivariante analysis using biplots. Department of Statistics, University of Salamanca. Retrieved from: http://biplot.usal.es/ClassicalBiplot/index.html.

Westphal, J. D., Seidel, M. D, \& Stewart, K. J. (2001). Second-order imitation: uncovering latent effects of board network ties. Administrative Science Quarterly, 46 (4), 717-747.

Young, R. (2004). Dilemmas and advances in corporate social responsibility in Brazil: the work of the Ethos Institute, Natural Resources Forum, 28 (4), 291-301. 